\title{
B-Cell Activating Factor Levels in Saliva and Serum before and after Treatment of Oral Infections
}

\author{
${ }^{1}$ Umit Karacayli, ${ }^{2}$ Neslihan Yilmaz, ${ }^{3}$ Muge Bicakcigil, ${ }^{4}$ Hale Cimilli, ${ }^{5}$ Sule Yavuz, ${ }^{6}$ Gonca Mumcu
}

\begin{abstract}
Background: B-cell activating factor belonging to the TNF family (BAFF) levels may increase in response to oral infections. The aim of the study was to evaluate saliva and serum BAFF levels in patients with oral infection and to monitor them after dental treatments.
\end{abstract}

Materials and methods: Fifteen patients with an oral infection foci including pericoronitis $(n=7)$ and irreversible pulpitis $(n=8)$ (F/M:10/5 mean age: $39.8 \pm 7.2$ years) were selected for the study. All patients were examined pretreatment period immediately and a week after endodontic treatment or oral surgical treatment. Unstimulated saliva and serum samples were collected from patients in these periods. Salivary and serum BAFF levels were measured by ELISA method (Bender, Medsystems, Viena, Austria).

Results: Since BAFF levels were similar in patients with irreversible pulpitis and pericoronitis $(p>0.05)$, two groups were combined in the study. Pretreatment salivary (median: 7.09 $\mathrm{ng} / \mathrm{ml}$ ) and serum BAFF levels $(3.28 \mathrm{ng} / \mathrm{ml})$ were significantly decreased after elimination of infection focus by endodontic or oral surgical treatments $(0.37$ vs 0.0$)(p=0.028$ and 0.002$)$. Saliva and serum BAFF levels were not correlated in pre- and post-treatment periods $(p>0.05)$.

Conclusion: Salivary and serum BAFF levels of patients with oral infections could be decreased by endodontic or oral surgical treatments.

Keywords: BAFF levels, Saliva, Serum, Pericoronitis endodontic and oral infection.

How to cite this article: Karacayli U, Yilmaz N, Bicakcigil M, Cimilli H, Yavuz S, Mumcu G. B-Cell Activating Factor Levels in Saliva and Serum before and after Treatment of Oral Infections. Int J Experiment Dent Sci 2014;3(2):63-66.

Source of support: Nil

Conflict of interest: None

\footnotetext{
${ }^{1}$ Associate Professor, ${ }^{2,3}$ Specialist, ${ }^{4-6}$ Professor

${ }^{1}$ Department of Oral and Maxillofacial Surgery, Gulhane Military Medical Academy, Turkey

2,3,5 Department of Rheumatology, Marmara University, Turkey

${ }^{4}$ Department of Endodontics, Marmara University, Turkey

${ }^{6}$ Department of Health Management, Marmara University Turkey

Corresponding Author: Umit Karacayli, Associate Professor Department of Oral and Maxillofacial Surgery, Gulhane Military Medical Academy, Turkey, Phone: 00903123046043 e-mail: ukaracayli@gmail.com
}

\section{INTRODUCTION}

B-cell activating factor (BAFF) known as tumor necrosis factor family is a cytokine and responsible for B-cell survival and maturation. ${ }^{1-3} \mathrm{~B}$-cell activating factor is secreted by myeloid cells regarding macrophages, monocytes and dendritic cells as well as nonlymphoid cells that are salivary gland cells, epithelial cells, astrocytes and fibroblast like astrocytes. ${ }^{4,5}$ Over expression of BAFF leads to increase in B-cell compartment and autoimmunity regarding systemic lupus erythematosus, rheumatoid arthritis and primary Sjögren syndrome. Since BAFF is found in sera, cerebrospinal fluid, synovial fluid and saliva of these patients, ${ }^{6-8}$ BAFF levels could be used to monitor disease and response to therapy. ${ }^{9}$ In our previous study, saliva and serum BAFF levels were lowered in patients with primary Sjögren syndrome (pSS) treated with hydroxychloroquine. ${ }^{10}$ Moreover, increase in BAFF levels are seen in the presence of inflammatory activity, since B-cell response increases in response to infections and pathogen clearance. ${ }^{1,2,12,13}$ It is unclear that oral infections as focal infection foci could trigger B-cell production in immune response. Therefore, the aim of the study was to evaluate saliva and serum BAFF levels in patients with oral infection and to monitor them after dental treatments.

\section{MATERIALS AND METHODS}

\section{Patients}

Patient group was composed of 15 dental patients having an oral infection focus in a single teeth (F/M:10/5 mean age: $39.8 \pm 7.2$ years). Among them, eight patients with symptomatic irreversible pulpitis were examined and diagnosed in department of Endodontic, Faculty of Dentistry, Marmara University. Seven patients with pericoronitis were examined in Oral and Maxillofacial Surgery, Clinic of Gulhane Military Medical Academy in the present study. The exclusion criteria were the presence of other systemic disease, oral mucosal lesions, salivary gland disorder, multiple oral infection foci including periodontitis, periapical periodontitis and medication usage affecting infection status in the group. Antibiotics were not used in pretreatment period of both groups. Analgesics were only taken by patients if necessary in first 3 days after treatments.

Data were collected by clinical examinations, serum and saliva samples. All patients were examined pretreatment 
period immediately and a week after endodontic treatment or oral surgical treatment. Saliva and serum samples were collected in these examinations.

\section{Symptomatic Irreversible Pulpitis}

Patients with only one tooth diagnosed as symptomatic irreversible pulpitis were selected in the study to eliminate confounding factors. No changes or minimal changes in the radiographic appearance of the periradicular bone were seen in radiographs of these patients. Pain and percussion sensitivity were the predominant conditions of patients with symptomatic irreversible pulpitis. The canals of these teeth were prepared and filled by using the step-back and lateral condensation techniques in the single-visit treatment (Table 1).

\section{Pericoronitis}

Patients with pericoronitis had a vertical partial impacted third molar. Spontaneous pain, localized swelling and drainage, affecting one lower third molar were the main clinical findings for patients with pericoronitis. In surgical procedure, a vestibular mucoperiosteal flap was raised with distal incision and vestibular release (Table 1).

\section{Salivary and Serum BAFF levels}

Unstimulated saliva samples were collected from the patients within 15 minutes between 9 and $12 \mathrm{AM}$ due to the circadian rhyme of saliva secretion. Salivary flow rates were calculated. ${ }^{14}$ Saliva samples were centrifuged at $15,000 \mathrm{rpm}$ for 10 minutes, supernatants were collected and stored $-80^{\circ} \mathrm{C}$. Then, serum samples were collected and immediately stored $-80^{\circ} \mathrm{C}$ until ELISA. It was carried out according to the manufacturer's protocol. The human BAFF ELISA that is an enzyme-linked immunosorbent assay for the quantitative detection of human BAFF, involves the stepwise addition and reaction of reagents to a solid phase-bound substance, through incubation and separation of bound and free reagents using washing steps. In quantifying the reaction, an enzymatic reaction is utilized to yield color by using of an enzyme-labeled reactant (Bender, Medsystems, Viena, Austria). ${ }^{13}$
The study was performed according to the principles of the decleration of Helsinki and was approved by the Ethical Committee of Marmara University Medical School. Informed consent was taken from patients.

\section{Statistical Analysis}

Data were analyzed by SPSS 11.5 analysis package program (SPSS Inc, Chicago, USA). Wilcoxon rank test was used to compare the parameters regarding BAFF levels at before and after treatments, Mann Withney U was used to compare data between irreversible pulpitis and pericoronitis. A p-value less than 0.05 is accepted to be significant.

\section{RESULTS}

Pretreatment period, saliva and serum BAFF levels in patients were similar in irreversible pulpitis (Saliva BAFF median: $7.09 \mathrm{ng} / \mathrm{ml}$, min-max: 0.0-26.35 $\mathrm{ng} / \mathrm{ml} v s$ serum BAFF median: $2.63 \mathrm{ng} / \mathrm{ml}, 0-9.73 \mathrm{ng} / \mathrm{ml}$ ) and pericoronitis (6.43 ng/ml, min-max: $0.0-48.50 \mathrm{ng} / \mathrm{ml}$ vs $3.28 \mathrm{ng} / \mathrm{ml},(0.0$ $18 \mathrm{ng} / \mathrm{ml})(\mathrm{p}=0.852$ and 0.548 respectively) (Table 2).

Same relations were seen in pericoronitis (Saliva BAFF median: $0.03 \mathrm{ng} / \mathrm{ml}$, min-max: 0.0-3.65 ng/ml vs serum BAFF median: $0.0 \mathrm{ng} / \mathrm{ml}, 0.0-0.9 \mathrm{ng} / \mathrm{ml}$ ) and irreversible pulpitis ( $1.49 \mathrm{ng} / \mathrm{ml} ; 0-6.18 \mathrm{ng} / \mathrm{ml} v s 0.0 \mathrm{ng} / \mathrm{ml}, 0.0-0.73 \mathrm{ng} / \mathrm{ml}$ ) after treatment ( $p=0.755$ and 1.0 respectively). Since no significant difference was seen in between irreversible pulpitis and pericoronitis, two groups were combined as oral infection group and then analyzed according to treatment (Table 2).

Salivary BAFF levels (median: $7.09 \mathrm{ng} / \mathrm{ml}$; min-max: $0-48.50 \mathrm{ng} / \mathrm{ml}$ ) in patients with oral infection before treatment were significantly higher than those of after dental treatments $(0.37 \mathrm{ng} / \mathrm{ml} ; 0-6.18 \mathrm{ng} / \mathrm{ml})(0.028)$ (Table 2). Serum BAFF levels $(0.0 \mathrm{ng} / \mathrm{ml} ; 0-0.73 \mathrm{ng} / \mathrm{ml})$ were lower before treatment compared to pretreatment period $(3.28 \mathrm{ng} / \mathrm{ml}$; 0-18 ng/ml (0.028) (Table 2). When BAFF levels were examined according to treatments in both groups separately, same results were seen in irreversible pulpitis group and pericoronitis group $(\mathrm{p}<0.05)$.

Saliva and serum BAFF levels were not correlated in both time period $(p>0.05)$. The median unstimulated saliva flow

Table 1: Clinical and radiological findings and treatment protocol of patients

\begin{tabular}{lll}
\hline & Irreversible pulpitis & Pericoronitis \\
\hline Clinical and & - Intermittent/spontaneous/sharp or dull type & - Spontaneous pain, localized swelling and \\
radiologic findings & localized pain & drainage around impacted teeth \\
& - Percution sensitivity & Vertical partial impacted \\
Treatment protocol & No or minimal changes in radiograhic changes & \\
& - Step-back and lateral condensation techniques & - Distal incision, raising vesibular mucoperiostal \\
& - So antibiotic usage & flap and vestibular release and osteotomy \\
& - Analgesics if necessary in first 3 days & - No antibiotic usage \\
\end{tabular}


Table 2: Salivary and serum BAFF levels before and after dental treatments

\begin{tabular}{|c|c|c|c|c|c|}
\hline & \multirow[t]{2}{*}{ Examination time } & \multicolumn{2}{|c|}{ Salivary BAFF levels (ng/ml) } & \multicolumn{2}{|c|}{ Serum BAFF levels $(n g / m l)$} \\
\hline & & Median & Min-max & Median & Min-max \\
\hline \multirow[t]{2}{*}{ Irreversible pulpitis } & Pretreatment period $^{\delta}$ & 7.09 & $0-26.35$ & 2.63 & $0-9.73$ \\
\hline & 1 week after treatment ${ }^{\beta}$ & 1.49 & $0-6.18$ & 0.0 & $0-0.73$ \\
\hline \multirow[t]{2}{*}{ Pericoronitis } & Pretreatment period ${ }^{\delta}$ & 6.43 & $0-48.5$ & 3.28 & $0-18$ \\
\hline & 1 week after treatment ${ }^{\beta}$ & 0.03 & $0-3.6$ & 0.0 & $0-0.9$ \\
\hline \multirow[t]{3}{*}{ Irreversible pulpitis and pericoronitis } & Pretreatment period & 7.09 & $0.0-48.5$ & 3.28 & $0.0-18$ \\
\hline & 1 week after treatment ${ }^{\beta}$ & 0.37 & $0-6.18$ & 0.0 & $0-0.9$ \\
\hline & $\mathrm{p}^{*}$ & 0.028 & & 0.002 & \\
\hline
\end{tabular}

${ }^{*}$ Wilcoxon rank test was used in the analysis; $\delta$ : Irreversible pulpitis-pericoronitis: Saliva BAFF levels, $p=0.852$; Serum BAFF levels, $p=0.548 ; \beta$ : Irreversible pulpitis-pericoronitis: Saliva BAFF levels, $p=0.755$, Serum BAFF levels, $p=1.0$

rate was observed a to be $1.70 \mathrm{ml} / \mathrm{second}$ (min-max: 1.3-1.9 $\mathrm{ml} / \mathrm{second}$ ) in the group. Salivary and serum BAFF levels were not correlated with salivary flow rate in them $(\mathrm{p}>0.05)$.

\section{DISCUSSION}

An oral infection is a focal infection focus and could affect B-cell responses in immunity. B-cell requires BAFF for their development, maturation and survival. BAFF levels are up regulated by interferon- $\gamma$, interleukin- 10 and CD40 ligand during inflammation and/or chronic infections. ${ }^{4,11,12}$ Yet, it is unknown whether the relationship between oral infections and BAFF levels.

After the elimination of oral infections by suitable dental treatments, serum and saliva BAFF levels were significantly decreased compared to baseline levels. Moreover, BAFF levels were similar in irreversible pulpitis and pericoronitis in both time periods. Similar to our results, increase in salivary BAFF levels is found in periodontal tissue infection and correlated with periodontal indices regarding modified gingival index, the papillary bleeding index, and the probing pocket depth in pSS. ${ }^{14,15}$ Similarly, elevated BAFF expressions are seen in the presence of viral infections, such as in human immunodeficiency virus, Epstein-Barr virus and hepatitis $C$ virus infections. ${ }^{4,11,12}$ Since chronic viral infections may enhance both cell apoptosis and release of nuclear antigens, activated dendritic cells express proinflammatory cytokines, such as BAFF. Therefore, BAFF stimulates B-cells to produce autoantibody and plays a key role in promoting B lymphocyte activation and survival. ${ }^{4}$

Oral health, a part of general health, is related with immune system response. Streptococci, Peptostreptococus, Prevotella, Porphyromonas and Fusobacterium are common microorganisms in odontogenic infections. ${ }^{16}$ Oral infections could spread maxillofacial area and lead to systemic symptoms. ${ }^{17,18}$ Bacterial products stimulates host cells for the secretion of proinflammatory cytokines during host defence. ${ }^{19}$ In irreversible pulpitis, tumor necrosis factor-alpha (TNF- $\alpha$ ) gene expression is related with severity of clinical symptoms in pulpal samples. ${ }^{20,21}$
Moreover, TNF- $\alpha$ and its receptors is found in pericoronitis by immunohistochemical staining method. ${ }^{20}$ In our previous study, salivary human neutrophil peptides 1-3 (HNP 1-3) levels, $\alpha$-defensin, are found to be low in patients with dental infections compared to healthy ones. ${ }^{22}$ Since immune system could be activated by oral infections, elevated BAFF levels could be predicted in patients with oral infections.

The present study had some limitations. First, limited number of patients was included in the study. Since the elimination of confounding factors was the critical point to evaluate BAFF levels, patients having single teeth with an oral infection were selected.

Second, although similar results were obtained in patients with irreversible pulpitis and pericoronitis, the combination of them led to inhomogeneity of the study group.

Third, patients were evaluated a week after dental treatments, since a new infection focus could affects BAFF levels. Yet, there was no data for BAFF levels in the followup period. The tissue healing process including different stages is affected by local and systemic factors. ${ }^{23}$ In shortterm experiments, time period could be used up to 7 days due to inflammatory process. ${ }^{24}$ According to our results, multiple sampling times are necessary to best understand the BAFF response.

Fourth, analgesics were used in first 3 days in both patient groups, whereas antibiotics were not used by patients. Oral infections lead to pain and tissue destruction. ${ }^{20}$ Pain is described as intermittent or spontaneous, sharp or dull localized form by patients with symptomatic irreversible pulpitis. ${ }^{24}$ In pericoronitis, osteotomy is carried out in the surgical procedure under local anesthesia. ${ }^{25}$ Third molar surgeries are associated with unpleasant experience for patients due to pain, swelling and immediate postoperative tissue reactions. ${ }^{25,26}$ As related with these clinical conditions, it was necessary to allow using analgesics that impact on tissue inflammation; however they might affect BAFF levels. Since the effects of antibiotics were unknown, they were not allowed to use by patients before and after treatments. Patients who needed antibiotic treatment were excluded in the study. 
The link between periodontal disease and systemic diseases has been scientifically proven over last two decades. The principle reason for this oral-systemic connection is dissemination of locally produced pro-inflammatory mediators. ${ }^{27}$

Consequently, this study was the first study evaluated BAFF levels in irreversible pulpitis and pericoronitis. Yet, further studies are needed to understand whether saliva or serum BAFF levels may be a reliable tool for the evaluation of oral infection foci in oral environment.

\section{REFERENCES}

1. Kalled SL, Ambrose C, Hsu YM. The biochemistry and biology of BAFF, APRIL and their receptors. Curr Dir Autoimmun 2005; 8:206-242.

2. Mackay F, Browning JL. BAFF: a fundamental survival factor for B-cells. Nat Rev Immunol 2002;2(7):465-475.

3. Mackay F, Schneider P, Rennert P, Browning J. BAFF and APRIL: a tutorial on B-cell survival. Annu Rev Immunol 2003; 21:231-264.

4. Lied GA, Berstad A. Functional and clinical aspects of the B-cellactivating factor (BAFF): a narrative review. Scand J Immunol 2011;73(1):1-7.

5. Schneider P, Tschopp J. BAFF and the regulation of B-cell survival. Immunol Lett 2003;88(1):57-62.

6. George-Chandy A, Trysberg E, Eriksson K. Raised intrathecal levels of APRIL and BAFF in patients with systemic lupus erythematosus: relationship to neuropsychiatric symptoms. Arthritis Res Ther 2008;10(4): R97.

7. Tan SM, Xu D, Roschke K, et al. Local production of B lymphocyte stimulator protein and APRIL in arthritic joints of patients with inflammatory arthritis. Arthritis Rheum 2003;48(4): 982-992.

8. Groom J, Kalled SL, Cutler AH, et al. Association of BAFF/ BLyS overexpression and altered B-cell differentiation with Sjogren's syndrome. J Clin Invest 2002;109(1):59-68.

9. Le Pottier L, Bendaoud B, Renaudineau Y, Youinou P, Pers JO, Daridon C. New ELISA for B-cell activating factor. Clin Chem 2009;55(10):1843-1851.

10. Mumcu G, Bicakcigil M, Yilmaz N, Ozay H, Karacayli U, Cimilli $\mathrm{H}$, Yavuz S. Salivary and serum B-cell activating factor (BAFF) levels after hydroxychloroquine treatment in primary Sjogren's syndrome. Oral Health Prev Dent 2013;11(3):229-234.

11. Sutherland AP, Ng LG, Fletcher CA, et al. BAFF augments certain Th1-associated inflammatory responses. J Immunol 2005;174(9):5537-5544

12. Sutherland AP, Mackay F, Mackay CR. Targeting BAFF: immunomodulation for autoimmune diseases and lymphomas. Pharmacol Ther 2006;112(3):774-786.
13. Crowther JR. Methods in Molecular Biology, The ELISA Guidebook, Vol. 516@ Humana Press, a part of Springer Science + Business Media, LLC 2009

14. Pers JO, Devauchelle V, Daridon C, et al. BAFF modulated repopulation of $\mathrm{B}$ lymphocytes in the blood and salivary glands of rituximab-treated patients with Sjogren's syndrome. Arthritis Rheum 2007;56(5):1464-1477.

15. Yavuz S, Asfuroglu E, Bicakcigil M, Toker E. Hydroxychloroquine improves dry eye symptoms of patients with primary Sjogren's syndrome. Rheumatol Int 2011;31(8):1045-1049.

16. Kuriyama T, Karasawa T, Nakagawa K, Saiki Y, Yamamoto E, Nakamura S. Bacteriologic features and antimicrobial susceptibility in isolates from orofacial odontogenic infections. Oral Surg Oral Med Oral Pathol Oral Radiol Endod 2000; 90(5):600-608.

17. Goolamali SI, Carulli MT, Davies UM. Spinal abscess and mitral valve endocarditis secondary to asymptomatic fusobacteriuminduced dental abscess. J R Soc Med 2006;99(7):368-369.

18. Grönholm L, Lemberg KK, Tjaderhane L, Lauhio A, Lindqvist $\mathrm{C}$, Rautemaa-Richardson R. The role of unfinished root canal treatment in odontogenic maxillofacial infections requiring hospital care. Clin Oral Investig 2012 Mar 14 [Epub ahead of print].

19. Lee JK, Kim HD, Lim SC. Predisposing factors of complicated deep neck infection: an analysis of 158 cases. Yonsei Med J 2007;48(1):55-62.

20. Beklen A, Laine M, Ventä I, Hyrkäs T, Konttinen YT. Role of TNF-alpha and its receptors in pericoronitis. J Dent Res 2005;84(12):1178-1182.

21. Kokkas AB, Goulas A, Varsamidis K, Mirtsou V, Tziafas D. Irreversible but not reversible pulpitis is associated with upregulation of tumour necrosis factor-alpha gene expression in human pulp. Int Endod J 2007;40(3):198-203.

22. Mumcu G, Cimilli H, Karacayli U, et al. Salivary levels of human neutrophil peptides 1-3 are related to oral ulcer activity in Behcet's disease. Int J Dermatol 2013 Oct;52(10):1198-1201.

23. Guo S, Dipietro LA. Factors affecting wound healing. J Dent Res 2010;89(3):219-229.

24. Goldberg M, Farges JC, Lacerda-Pinheiro S, et al. Inflammatory and immunological aspects of dental pulp repair. Pharmacol Res 2008;58(2):137-147.

25. Chiapasco M, De Cicco L, Marroneh K. Side effects and complications associated with third molar surgery. Oral Surg Oral Med Oral Pathol 1993 Oct;76(4):412-420.

26. Kirk DG, Liston PN, Tong DC, Love RM. Influence of two different flap designs on incidence of pain, swelling, trismus, and alveolar osteitis in the week following third molar surgery. Oral Surg Oral Med Oral Pathol Oral Radiol Endod 2007 July;104(1):e1-e6.

27. Saini R. A clinical and microbiological study to evaluate the effect of dietary supplement of coenzyme Q10 in nonsurgical treatment outcome of chronic periodontitis patients after phase 1 periodontal therapy. Eur J Gen Dent 2014;3:194-198. 